\title{
THE 1619 PROJECT AND THE IMPORTANCE OF HISTORICAL SIGNIFICANCE AND ARGUMENTATION IN THE HISTORY AND SOCIAL STUDIES CLASSROOM
}

\section{Andrew Erford}

Bloomington High School

Bloomington, Illinois
Teaching History 46(2)

DOI: $10.33043 /$ TH.46.2.30-34

(C) 2021 Erford.

Distributed with CC BY-NC-ND 4.0 License.

History has never simply been the study of a series of straightforward, unquestionable, and universal facts. Historians and importantly, students, engage in research and produce scholarship that brings meaning to the past through historical interpretation, analysis, and argumentation. In a recent iteration of Americass culture wars - the history wars-a very public, vociferous, and often hostile debate rages, focusing on how history should be properly taught in American classrooms. Controversies surrounding The New York Times Magazine's 1619 Project typify one aspect of the current "history wars." Editor Jake Silverstein and project creator Nikole Hannah-Jones, both journalists by training and trade, along with the other project authors, produced a work of popular historical scholarship arguing that the United States' origin story should be centered on the arrival of enslaved Africans on the English colonial shores in America in 1619. ${ }^{1}$ This interpretation differs from several other approaches to American history. ${ }^{2}$ By asserting that 1619 is the proper beginning to the American story, the 1619 Project is merely positing an argument. This historical argument is controversial within the academy and across the mass media landscape. Whether it makes a strong or a weak argument, the 1619 Project's thesis has much to offer students of history because it calls attention to historical argumentation, historical significance, and secondary sources.

Silverstein, Hannah-Jones, and the other essay authors argue that 1619 is the basis for discussing America's founding. In addition, Hannah-Jones asserted that the Revolutionary War was fought to protect the institution of slavery. Scholars pushed back. Prominent American historian Sean Wilentz was reportedly so enraged by the project's argument regarding the Revolutionary War that he threw his copy of The New York Times Magazine across the room upon reading it. ${ }^{3}$ By contrast, former CEO of Chicago Public Schools (CPS) and former social studies teacher, Janice K. Jackson was said to be left breathless after reading the 1619 Project's interpretation. ${ }^{4}$ Subsequently, CPS decided to integrate the project into their social studies curriculum, and they received hundreds of copies of the publication for classroom use. ${ }^{5}$ Likewise, school districts in other major cities decided to integrate the project into their social studies curriculums. ${ }^{6}$ This news resulted in a legislative and media backlash, moving some to ban the project in schools and paint it as too radical for educational use. ${ }^{7}$

Most middle school or high school teachers have likely experienced rampant student demands to spend

\footnotetext{
${ }^{1}$ Jake Silverstein, “The 1619 Project,” The New York Times Magazine, August 18, 2019, 4; Nikole Hannah-Jones, “The 1619 Project," The New York Times Magazine, August 18, 2019, 16-17.

${ }^{2}$ For example, see sociologist Matthew Desmond's essay contribution in which he argues that slavery has heavily impacted the modern American economy. This sparked intellectual criticism from a variety of perspectives: Phillip W. Magness, "The Case for Retracting Matthew Desmond's 1619 Project Essay," American Institute for Economic Research, February 11, 2020, https://www. aier.org/article/the-case-for-retracting-matthew-desmonds-1619-project-essay/; Allen C. Guelzo, "The 1619 Project Tells a False Story About Capitalism, Too," Wall Street Journal, May 8, 2020, https://www.wsj.com/articles/the-1619-project-tells-a-false-storyabout-capitalism-too-11588956387; John Clegg, "How Slavery Shaped American Capitalism: The New York Times is Right That Slavery Made a Major Contribution to Capitalist Development in the United States — Just Not in the Way They Imagine," Jacobin, August 28, 2019, https://jacobinmag.com/2019/08/how-slavery-shaped-american-capitalism

${ }^{3}$ Sarah Ellison, "How the 1619 Project took over 2020," The Washington Post, October 13, 2020, https://www.washingtonpost.com/ lifestyle/style/1619-project-took-over-2020-inside-story/2020/10/13/af537092-00df-11eb-897d-3a6201d6643f story.html.

${ }^{4}$ Janice K. Jackson, “The 1619 Project and Chicago Public Schools," Inside CPS, September 17, 2019, https://blog.cps.

edu/2019/09/17/the-1619-project-and-chicago-public-schools/

${ }^{5}$ Ibid.

${ }^{6}$ Robby Soave, "Public Schools are Teaching The 1619 Project in Class, Despite Concerns from Historians," Reason, January 28, 2020, https://reason.com/2020/01/28/1619-project-new-york-times-public-schools/

${ }^{7}$ Sarah Swartz, "Lawmakers Push to Ban '1619 Project’ From Schools,” EducationWeek, February 3, 2021.
} 
valuable and limited class time watching or discussing the latest popular movie or discussing popular video games, memes, or sports. In the fall semester of 2020, during Zoom-based remote learning in the midst of a global pandemic, many of my students wanted to discuss the 1619 Project, African American history, slavery, Jim Crow, institutionalized racism, Black Lives Matter, police brutality, cash bail inequity, and numerous other racially relevant topics. For all its omissions, factual errors, and its indictment by some historians as lacking intellectual rigor, the 1619 Project not only inspired historical discussion among students and the public; it brought the concepts of historical significance and argumentation into the forefront of historical discussion. By asking students, "When did American history begin?" teachers can help students consider how and why we emphasize specific events and how they can use evidence to build arguments.

\section{Historical Significance}

The 1619 Project makes a historical argument with respect to historical significance. Luckily, various scholars, journalists, critics, and pundits have offered competing narratives about significant events and dates in U.S. history. These competing arguments are compelling fodder for student consumption and analysis. 1776 Unites, an interdisciplinary and interprofessional project of ideologically and racially diverse thinkers has situated 1776 as the basis for studying American history, arguing that our founding principles and documents unite us as Americans and arguing against what they deem to be "grievance politics." 8 Journalist Conor Friedersdorf takes a much softer approach, arguing that 1776 is the proper beginning of American history, because even America's most ardent dissenters quoted the Declaration of Independence and the ideals it articulates, providing us with a shared foundation. ${ }^{9}$

In his recent book, 1620: A Critical Response to the 1619 Project, former professor of anthropology and conservative journalist Peter W. Wood argues that 1620 and the Mayflower Compact represent the true founding of the United States. ${ }^{10}$ The New York Times' conservative opinion columnist, Ross Douthat, also situates U.S. origins within the colonial period. Douthat argues that the French and Indian War is one of the most important wars in world history and that it is far more important to American history that the Revolutionary War. ${ }^{11}$ The 1619 Project and its ensuing debate led The Philadelphia Inquirer to consult four historians to determine when the American story began. ${ }^{12}$ Because the four historians present differing scholarly arguments regarding the beginning of American history within the same accessible article, students can easily read, write, and discuss the topic with minimal preparation. All of these authors are in conversation with the 1619 Project, and their diverse perspectives should be embraced, rather than avoided. Engaging students in examining how authors build different positions is a valuable use of classroom time.

\section{Building Historical Arguments Through Questions}

Effective history teachers typically rely on some form of "hook" to foster student interest, such as a controversial or funny image, video, or quote, or even a short activity to demonstrate an injustice or controversy. Beginning an American history course with a spirited debate over the question, "When did American history begin?" allows students to consider competing historical perspectives: those that are based on patriotism and the founding of the United States, those that focus on a specific demographic population, such as African Americans, and those that embrace American history prior to the arrival of Europeans on

\footnotetext{
${ }^{8} 1776$ Unites, "Our Declaration,” 1776 Unites, https://1776unites.com/

${ }^{9}$ Conor Friedersdorf, “1776 Honors America’s Diversity in a Way 1619 Does Not,” The Atlantic, January 6, 2020, https://www. theatlantic.com/ideas/archive/2020/01/inclusive-case-1776-not-1619/604435/

${ }^{10}$ Peter W. Wood, 1620: A Critical Response to the 1619 Project (New York: Encounter Books, 2020), 23-24.

${ }^{11}$ Ross Douthat, "The War That Made Our World," The New York Times, July 13, 2021, https://www.nytimes.com/2021/07/13/ opinion/french-indian-war-american-history.html

${ }^{12}$ Staff Reports, "The 1619 Anniversary: Where Does the American Story Begin? Opinion," The Philadelphia Inquirer, September $15,2019$.
} 
American shores. Even within the focus on European arrival, perspectives differ, as some historians may focus on British, French, or Spanish colonialization, while others may focus on the Caribbean or Central and South American colonization by Europeans. Regardless, all of these perspectives have merits and faults, each presenting students with choices when formulating their historical arguments. This is not a new concept, nor is it particularly profound. However, students who are below grade level in literacy levels, students who demonstrate an average level of mastery in historical thinking, and students who are the highest motivated and highest achieving in the history classroom can all access and benefit from considering the following questions and amassing evidence to build their argument:

- When did American history begin?

- When is the true founding of the United States?

- When does the American story begin?

Likewise, the same instructional approach can be applied to defining the idea of America:

- What is America?

- What is an American?

- What does it mean to be an American?

- Where is America?

- How has America influenced and shaped the rest of the world?

Teaching history and social studies in the K-12 classroom is always a challenging endeavor. It is impossible to "cover" everything in history in a single academic year, and even seven years of instruction across middle school and high school are not enough time to cover the entirety of American and world history, as well as civics, geography, economics, psychology, sociology, anthropology, and various other electives. The use of simple, fundamental questions, whether using time, place, or definition, offers students the opportunity to apply historical thinking skills, employ historical arguments, and engage historical controversies in a straightforward manner that is compatible with the time limitations and often chaotic nature of K-12 teaching and learning in the United States.

\section{Student-Centered Classrooms to Promote Building Arguments}

One of the most damning critiques of history and social studies education in the United States is that students are not the driving force in most classrooms. The use of significance as a starting point for teaching and learning history and engaging students in building arguments aligns with Paulo Freire's argument against "banking" models of education that keep content in the hands of the instructor. As Freire points out, peasants typically identify themselves as ignorant and see their teachers as those who have the knowledge that they need. Freire notes that they rarely believe they know things that are relevant to what is being studied. ${ }^{13}$ The obvious benefit of all types of inquiry-based teaching and learning is that it pushes back against the inherently teacher-centered forms of instruction that most often take root in K-12 classrooms. When students drive the learning process by engaging fundamental questions, students are able to assert their agency and tailor their historical education to their needs. History textbooks and lecture-based history often lead with essential questions, but then follow with answers. This approach teaches students that there is either one correct answer to every historical question, or it influences students to fall in line with arguments presented by their teachers and/or textbooks. If the goal of history and social studies education in the United States is to produce citizens capable of thinking critically about our shared past, present, and future, then students need to become adept at engaging difficult historical questions and developing strong historical arguments that they believe in. In other words, parroting reflexive responses to historical questions that use one or more primary sources to "prove" an argument does not have

\footnotetext{
${ }^{13}$ Paulo Freire, The Pedagogy of the Oppressed, 30 ${ }^{\text {th }}$ Anniversary Edition (New York: Continuum, 2005$), 63$.
} 
the same value or rigor as interrogating the question of when American history began. Student arguments and products, such as their verbal and written responses, are likely to be sloppy and look nothing like graduate and professional historical scholarship, but that is okay. Students benefit when they think big and attempt to place themselves and others within the context of history. The 1619 Project and the competing reactions it inspired are useful because they are not final answers to historical questions. Rather, they can engage students in a perpetual conversation of historical study.

\section{The Value of Secondary Sources}

Former President Trump's short-lived 1776 Commission, which produced the 1776 Report, places immense importance upon producing good American citizens and the teaching and learning of facts within the study of history and social studies. The commission argues that we must "reject false and fashionable ideologies that obscure facts, ignore historical context, and tell America's story solely as one of oppression and victimhood rather than one of imperfection but also unprecedented achievement toward freedom, happiness, and fairness for all." 14 The commission also argues that civics and government education should "rely almost exclusively on primary sources." 15 This a subtle, yet substantial argument against the use of secondary sources in social studies instruction. When students traffic in historical argumentation, they are joining the discourses contained within various historiographies. Though primary sources are undoubtedly important to the study of history, so is the wonderfully diverse library of secondary analysis.

To the members of the 1776 Commission, students become damaged goods when they read thinkers such as Howard Zinn, Noam Chomsky, Ayn Rand, Karl Marx, Paulo Freire, and Max Weber. But, students are only damaged when they read secondary sources as an/the end truth. Otherwise, students grow by adding more and more perspectives to their understanding of history. Reading Hitler's Mein Kampf does not make the reader a Nazi, nor does reading Marx's Communist Manifesto make the reader a communist. However, reading either text as absolute truth can be detrimental.

Textbook publishers are notoriously bad at engaging Native American history and incorporating Native Americans into their for-profit textbooks. Students reap only benefits by reading and discussing Native American scholars such as Vine Deloria, Jr., Nick Estes, Roxanne Dunbar-Ortiz, David Treuer, Dino Gilio-Whitaker, and Thomas King. Students can benefit even more by juxtaposing these scholars' arguments with those posited by previous generations of Native American scholars, finding where they agree, disagree, and what they ignore. Excerpts, book chapters, and articles are as easily consumed by students as primary source documents, which are often difficult due to the unfamiliar writing styles and vocabulary words employed by the authors. The 1776 Commission appears to have an interest in keeping students away from secondary sources, such as the 1619 Project, which make historical arguments with which students can easily engage.

\section{Conclusion}

No historian or social studies educator has unequivocally found the perfect approach to teaching history. Not every student will respond to even the most controversial, fun, and/or exciting readings and instructional activities. A simple and affordable way to engage students at the beginning of a history course and at the beginning of units and modules is to work through questions of when, where, and what. This demonstrates the importance of historical perspective, interpretation, and argument, easily dispelling the notion that studying history is merely the acquisition of a series of irrefutable facts. It also naturally provides students with agency, as their arguments take center stage, while still requiring students to engage primary and secondary sources and support their arguments with evidence. Because of this, the 1619 Project is not an evil or indoctrinating document that will damage those students who read and examine it. Nor is it a publication that an entire curriculum should be centered around-American history is just too vast to center around any single text. It is

\footnotetext{
${ }^{14}$ The President's Advisory 1776 Commission, “The 1776 Report,” January 2021, 18.

${ }^{15}$ Ibid., 38.
} 
merely another great contribution to the historiography of American history. The 1619 Project, with every other worthy historical argument, needs to be discussed, critiqued, and defended, rather than censored or placed upon a divine intellectual pedestal. 